\title{
Anterior segment optical coherence tomography of iridoschisis
}

\author{
Rohit Agarwal, ${ }^{1}$ Koushik Tripathy (1) ,' Mayank Jain 우 ${ }^{2}$
}

ASG Eye Hospital Kolkata, Kolkata, India

${ }^{2}$ Paediatric Ophthalmology, Strabismus and Neuroophthalmology, ASG Eye Hospitals, Bhopal, India

\section{Correspondence to}

Dr Mayank Jain;

sandymayank@gmail.com

Accepted 21 September 2021

\section{DESCRIPTION}

A 50-year-old man had bilateral inferior atrophic patches on the iris with visible iris fibrils (shreddedwheat appearance) some of which were floating in the anterior chamber (figure 1). ${ }^{1}$ There was no previous history of pain, redness, trauma or any ocular procedure. Corneal sensation was normal in both eyes. Anterior segment optical coherence tomography shows disruption of the anterior limiting layer of the iris, shadow due to floating iris tissue in the anterior chamber, intact pigmented epithelium of the iris and splitting of the stroma with moth-eaten appearance (figure 2) suggestive

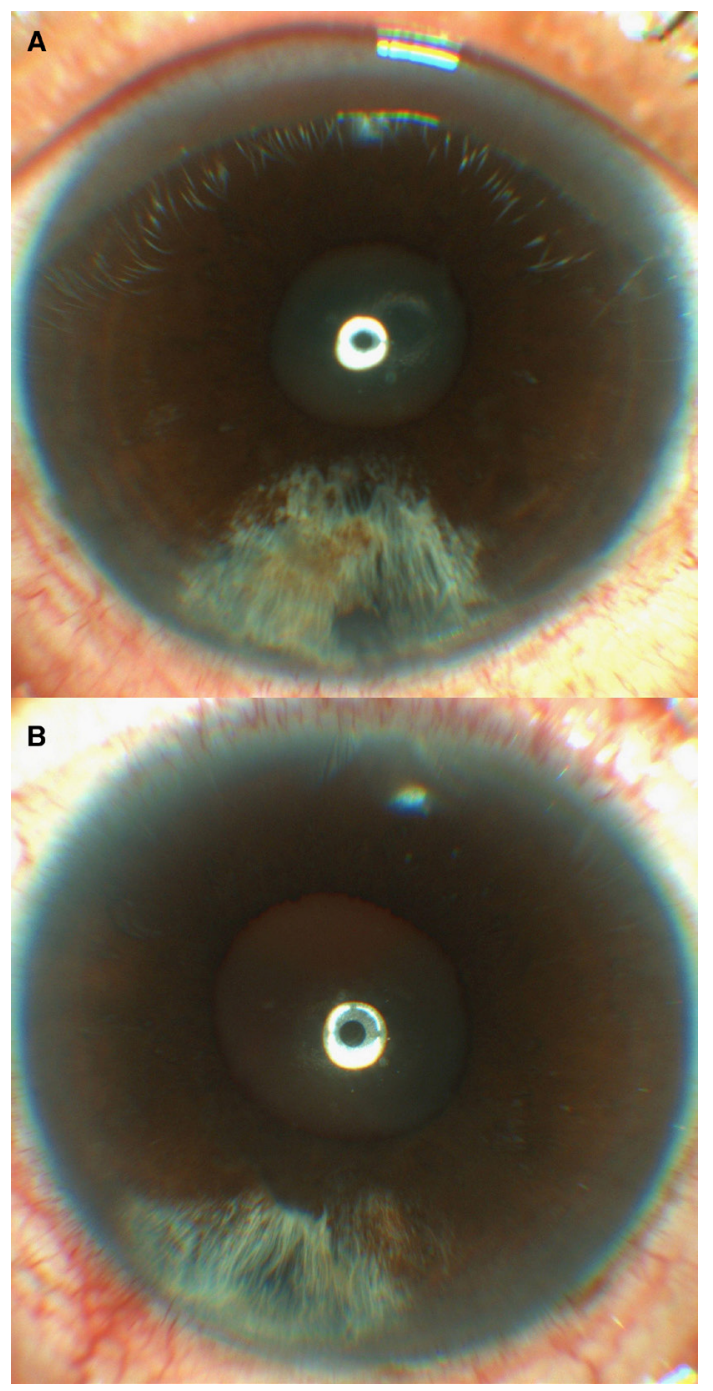

Figure 1 Slit-lamp photo of the right $(A)$ and the left (B) eye showing an inferior patch of iris atrophy and a shredded-wheat appearance.

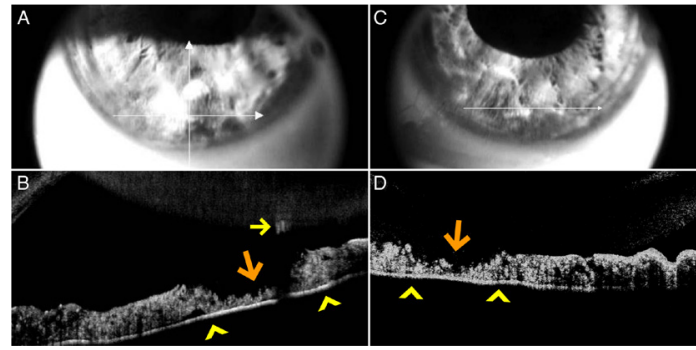

Figure 2 The anterior segment optical coherence tomography of the right eye ( $A$ and $B$ ) and the left eye $(C$ and $D)$ showing disruption of the anterior limiting layer of the iris, splitting of the stroma with moth-eaten appearance (orange arrow), shadow due to floating iris tissue (yellow arrow) in the anterior chamber and intact pigmented epithelium of the iris (arrowheads) suggestive of iridoschisis.

of iridoschisis. ${ }^{2}$ Iridoschisis is often associated with angle-closure glaucoma, corneal oedema or lens abnormalities. ${ }^{34}$ It is necessary to follow-up with these patients to screen for such changes and treat them accordingly. ${ }^{4}$

\section{Learning points}

- Iridoschisis usually presents as bilateral inferior atrophic patches of the iris.

- Anterior segment optical coherence tomography demonstrates the alterations in the affected iris vividly.

- Regular follow-up is required to screen for glaucoma, cornea and lens-related abnormalities.

Twitter Koushik Tripathy @koushiktripathy

Acknowledgements Dr Gopal Bandyopadhyay, Dr Himanshu Shekhar, Dr Kishore Kumar Vatwani, Dr Koushik Basu.

Contributors KT diagnosed the condition, investigated and advised treatment. RA was involved in collection of images with valid consent. KT and RA was involved in drafting the manuscript of the case report. KT, MJ and RA revised the manuscript and maintained the standards of the manuscript as per BMJ protocols. The final manuscript was approved by all the four authors, that is, RA, KT and MJ. All authors are responsible for the integrity and accuracy of the data provided.

Funding The authors have not declared a specific grant for this research from any funding agency in the public, commercial or not-for-profit sectors

Competing interests None declared.

Patient consent for publication Consent obtained directly from patient(s).

Provenance and peer review Not commissioned; externally peer reviewed. 
Images in...

\section{ORCID iDs}

Koushik Tripathy http://orcid.org/0000-0002-9756-128X

Mayank Jain http://orcid.org/0000-0002-8314-4725

\section{REFERENCES}

1 Chen Y, Qian Y, Lu P. Iridoschisis: a case report and literature review. BMC Ophthalmol 2017; 17:1-6.
2 Paniagua L, Bande MF, Rodríguez-Ares MT, et al. A presentation of iridoschisis with plateau iris: an imaging study. Clin Exp Optom 2015;98:290-1.

3 Omoto T, Agata C, Akiyama R, et al. Iridotrabecular and iridocorneal contact changes after cataract surgery and endothelial keratoplasty in bilateral Iridoschisis. Case Rep Ophthalmol 2021;12:198-203.

4 Pieklarz B, Grochowski ET, Saeed E, et al. Iridoschisis-A systematic review. J Clin Med 2020;9:3324-20.

Copyright 2021 BMJ Publishing Group. All rights reserved. For permission to reuse any of this content visit

https://www.bmj.com/company/products-services/rights-and-licensing/permissions/

BMJ Case Report Fellows may re-use this article for personal use and teaching without any further permission.

Become a Fellow of BMJ Case Reports today and you can:

- Submit as many cases as you like

- Enjoy fast sympathetic peer review and rapid publication of accepted articles

Access all the published articles

Re-use any of the published material for personal use and teaching without further permission

\section{Customer Service}

If you have any further queries about your subscription, please contact our customer services team on +44 (0) 2071111105 or via email at support@bmj.com.

Visit casereports.bmj.com for more articles like this and to become a Fellow 